\title{
PROTEIN TEACHING: AN APPROACH FOR TEACHER TRAINING APPLIED TO STUDENTS OF THE BIOLOGICAL SCIENCES COURSE AT UFRN
}

\author{
NASCIMENTO, JKS ${ }^{1}$; MEDEIROS, MVS ${ }^{1}$; FRANÇA, DF'; FILGUEIRA, LGA ${ }^{1}$; \\ ANDRADE, GPV'; MATTA, LDM' ${ }^{1}$. \\ 'Departamento de Bioquímica, UFRN, Natal-RN, Brazil
}

Teaching biochemistry in higher education is increasingly becoming a challenge. It is notoriously difficult for students to assimilate the topic; in addition there are many complaints about the complexity of subjects and a lack of integration with the day-today. A recurrent problem in undergraduate courses is the absence of teaching practice in specific disciplines. This work aimed to stimulate students in the biological sciences course who were enrolled in the discipline of MOLECULAR DIVERSITY (MD), to create hypothetical classes focused on basic education highlighting the proteins topic. The methodology was applied in a class that contained 35 students. Seven groups were formed, and each group chose a protein to be used as a source of study for elementary school classes. A lesson plan was created focusing on the methodology that the group would use to manage a class. The class was to be presented orally. Students were induced to be creative and incorporate a teacher figure, and to propose teaching methodologies for research using the CTS approach (Science, Technology and Society). Each group presented a three-dimensional structure of the protein they had chosen, explained their structural features and functions and how they would develop the theme for a class of basic education, and what kind of methodology they would use for this purpose. At the end of the presentations, a questionnaire was given to students in order to evaluate the effectiveness of the methodology in the teaching-learning process. The activity improved the teacher's training and developed skills and abilities, such as creativity, didactical planning, teaching ability, development of educational models and the use of new technologies. The methodology used in this work was extremely important to the training of future teachers, who were able to better understand the content covered in the discipline and relate it to day-to-day life.

Keywords: Educational models; teacher training; meaningful learning. 